\title{
Estimation of Rock Aggregates Quality Using Analyses of Drill Cuttings
}

\author{
Eva Johansson, Karel Miskovsky, and Karl-Johan Loorents
}

(Submitted May 14, 2008; in revised form July 4, 2008)

\begin{abstract}
There is a need for an effective method to estimate the quality of crushed rock aggregates and its usability in the early stages of project planning, e.g., for road and railway constructions and quarry prospecting. The proposed method is based on mineralogical and petrographic analyses of drill cuttings and analysis of the coarse fraction to estimate the homogeneity/heterogeneity of the bedrock. The geological analyses are followed by an estimation of the rock materials' mechanical properties and their potential technical usability. Development and practical applicability (field and laboratory) of the method have been performed and correlated to three road projects from regions of different geological and climatic zones in Sweden. The study confirms the capability of the proposed method as a surveying tool.
\end{abstract}

Keywords aggregates, drill cuttings, mechanical properties, petrographic analysis, road constructions

\section{Introduction}

To minimize the environmental consequences and costs for road and railway construction works, a careful use of rock aggregates within the construction site is required (e.g., Ref 1). An early estimation of the quality of the bedrock and its optimum use (i.e., mass and material balance) demands an appropriate level of survey. Misjudgments of the use of such aggregates may cause considerable negative economic and construction consequences. The early information concerning the quality of the bedrock is especially true for areas of low bedrock exposure covered by drift materials.

In modern society, the attention is paid to economical profitability, environmental protection, and a sustainable usage of resources. According to these requisites, the aggregates must also meet constructional requirements. In an effort to reach the object-related volumetric and material equilibrium of rock mass for infrastructure construction, there is a need for a robust tool for balance calculations.

The central prerequisite in prospecting of natural resources such as rock materials is the knowledge of the qualities that determine the suitability of a material for use as aggregates (Ref 2). The strong relationships between geological properties (e.g., the mineralogical composition and the rock fabrics), mechanical properties, and the rock mass' likely performance as an aggregate in construction must be taken into account when deciding on new extraction sites for aggregates (Ref 3 ).

Eva Johansson and Karel Miskovsky, Department of Civil, Mining and Environmental Engineering, Luleå University of Technology, 97187 Luleå, Sweden; and Karl-Johan Loorents, The Swedish Road Administration, 40533 Göteborg, Sweden. Contact e-mails: eva.johan sson@ltu.se,miskovsky@telia.com and karl-johan.loorents@vv.se.
Analysis of drill cuttings is an established surveying tool extensively used in ore prospecting. The traditional prospecting for crushed rock aggregate quarries is so far based on drill-cores used for petrographic and mechanical analyses. The method presented is focused on petrographic analysis of the coarse fraction ( $>4 \mathrm{~mm}$ ) of drill cuttings to estimate the homogeneity/ heterogeneity of the bedrock and to determine the rock types included. This information in turn admits assessment of mechanical properties and technical usability in construction applications (e.g., roads and railways). The fine fraction $(0.125$ $0.25 \mathrm{~mm}$ ) is used to estimate the content of free mica particles. It is known that mica-bearing rocks may cause damage in road constructions (e.g., Ref 4-6). The deterioration of the construction is related to the ability of mica particles to be released during crushing and to concentrate in the aggregate fine fractions. Enrichment of free mica particles in the aggregate fine fractions and its effects on the quality of crushed rock aggregate products applied in constructions are thoroughly described in Ref 4-9.

The purpose of the current study was to examine the possibility of using drill cuttings for estimation of the quality of rock aggregates as construction materials. Furthermore, the work is used to develop and test the practical application, and the efficiency of the method, within a number of road projects from regions of different geological and climatic zones in Sweden.

\section{Methods}

\subsection{Project Design}

The practical application of using drill cuttings for estimation of the rock aggregates quality was designed according to three phases; each adapted to the state of the road project.

The first phase is focused on geological map studies, initial field work, and sampling. Map studies provide indications about the structure of the bedrock and the types of rock. The field investigation is aimed toward ocular inspection of the projecting area. In this stage, the locations and number of sampling points (i.e., bore holes) are determined. The approximate 
depth of the bore holes is $5 \mathrm{~m}$, which is the regular depth used for soil/rock probing (i.e., geotechnical investigations) for advanced construction projects (e.g., bridges and under ground constructions; Ref 10). The depth is selected based on the properties of the bedrock, and the bore holes may be deeper if the geology is complicated or heterogeneous. During the sampling it is of great importance to collect large enough samples of coarse drill cuttings for the reliability (statistical) of the prediction. The samples are reduced and dry sieved, and narrow size fractions $(0.125-0.25$ and $>4 \mathrm{~mm})$ are collected according to Ref 11 and 12. From each of the collected size fractions, thin sections are prepared (Ref 13, 14) and micro photographed to allow for digital analysis. The coarse fraction is used for petrographic analysis while the fine fraction is used to estimate mineralogical composition (e.g., free mica particles). When the rock type and the mineralogical composition are known, the quality of the aggregate, aggregate mechanical

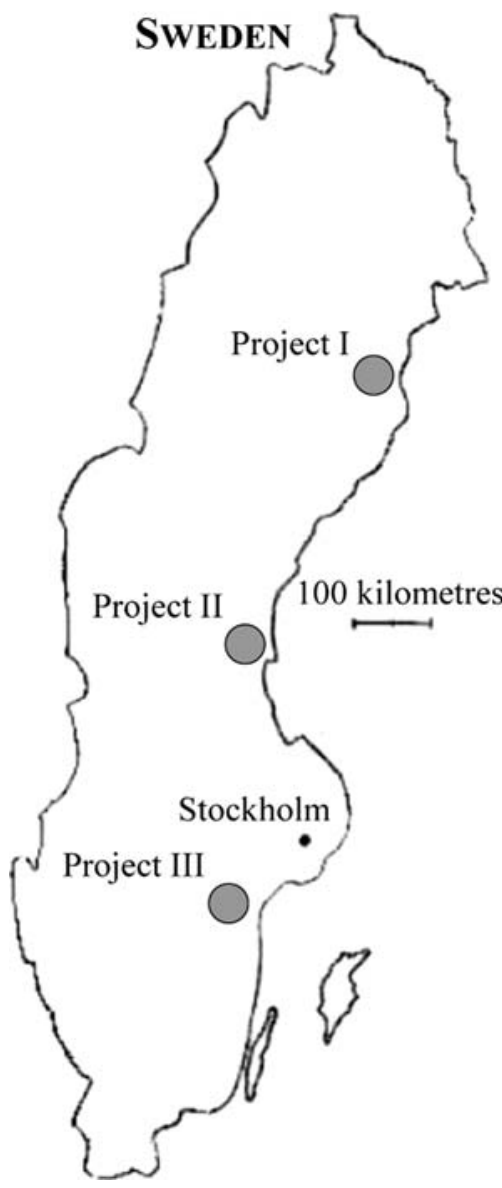

Fig. 1 The locations of the projects studied properties, and possible usage can be estimated. As a framework for construction and material demands, technical norms (Ref 15) for road constructions from the Swedish Road Administration are applied.

Within the second phase a complementary field investigation is carried out after drift materials have been cleared and the bedrock exposed. The rock structures are subsequently mapped and samples from the bedrock and from the production (i.e., crushing) are collected for mechanical and petrographic analyses. The outcome is compared with the results from phase 1 .

Phase 3 includes functional control of the rock aggregates pertaining to sampling from the construction and testing of the rock material. At this stage a final summary comparison of all results is performed and the method of drill cuttings is evaluated with respect to reliability, efficiency, and economic aspects.

Field studies included three road projects that were located in the north, central, and southeast regions of Sweden (Fig. 1). Project I comprised phases 1 and 2 while Project II comprised phase 1. In Project III, phases 1 and 2 were carried out simultaneously. It was not possible to complete phase 3 in any of the projects studied, due to time constraints.

\subsection{Petrographic Analyses}

The analyses of the coarse fraction $(>4 \mathrm{~mm}$ ) were performed under a polarizing microscope and the mineralogical composition of the rocks was determined by point-counting (e.g., Ref 13, 16, 17). The estimation of free mica particles in aggregate fine fractions was carried out by image analysis as described in Ref 18. The method used in the present study is based on a modified point-count approach, using micro photographs of thin sections and a software package for analysis and presentation of the data.

\subsection{Mechanical Analyses}

To confirm the validity of the mechanical properties predicted in the first phase, samples collected in phase 2 were tested for resistance to wear (micro-Deval value), resistance to fragmentation (Los Angeles value), resistance to wear by abrasion from studded tyres (Nordic test value), and particle shape (flakiness index). All tests were performed by accredited laboratories in accordance with Ref 11, 12, 19-23.

\section{Results}

\subsection{Project I}

Previous studies of geological maps indicated bedrock dominated by meta-greywacke (sediment-gneisses, veined

Table 1 Results of the petrographic analyses, Project I, phase 1; rock type and mineralogical composition

\begin{tabular}{|c|c|c|c|c|c|c|}
\hline Sample ID & Rock type & Grain size, $\mathbf{m m}$ & Plagioclase, vol.\% & Quartz, vol.\% & Mica, vol.\% & Others, vol. \% \\
\hline P1-1-01 & Mica-schist & 0.5 & 36.6 & 35.5 & 27.8 & $\ldots$ \\
\hline P1-1-02 & Mica-schist & $0.5-1$ & 32.2 & 48.4 & 19.4 & $\ldots$ \\
\hline P1-1-03 & Mica-schist & $0.3-0.5$ & 48.5 & 31.5 & 18.0 & 2.0 \\
\hline P1-1-04 & Mica-schist & $0.3-0.5$ & 30.2 & 38.2 & 31.6 & $\ldots$ \\
\hline P1-1-05 & Mica-schist & $0.3-1$ & 38.5 & 48.5 & 13.0 & $\ldots$ \\
\hline P1-1-06 & Mica-schist & $0.4-5$ & 48.9 & 38.7 & 10.6 & 1.7 \\
\hline P1-1-07 & Mica-schist & $0.2-0.7$ & 38.0 & 46.9 & 11.3 & 3.8 \\
\hline
\end{tabular}


gneisses, mica-schists, and phyllites) and by limited occurrence of ortho-gneisses of granitoid composition (Ref 24). The results of the petrographic analyses of drill cuttings pointed out a dominance of grey to dark grey, strongly foliated, mediumgrained mica-schist with the mineralogical composition of quartz $>$ feldspar (plagioclase) $>$ mica (biotite) (Table 1). The content of free mica particles in the fine fractions varied from 24 to nearly $50 \%$ (Table 2 ).

On the basis of the petrographic analyses, the mechanical properties and the usability were empirically estimated with consideration to the project design. The examined rock types were considered hardly qualified for use as sub-base course in unbounded road pavements (Ref 15). Due to the heterogeneity of the bedrock and the high free mica particle content in fine fractions, it was estimated that the rock quality would not satisfy the construction demands for the base course.

The field investigation, the complementary geological analyses, and the mechanical tests in accordance with phase 2 confirmed the prognosis given in phase 1 . The results of the petrographic analyses and the geological investigations showed heterogeneous bedrock dominated of coarse-grained, veined sedimentary gneiss alternating with dark, medium-grained mica-schist, and dark, medium- to coarse-grained ortho-gneiss (Table 3). All these rock types are mica-rich. The content of free mica particles in the fine fractions was calculated as $33-45 \%$ (Table 4). The predicted mechanical properties corresponded well with the mechanical tests (Table 5). Because of the heterogeneity of the bedrock, the test results should be considered as averages. The results from the mineralogical and petrographic examinations carried out in Project I pointed out that the rock material within the construction site was not suitable for use as base course, and as sub-base course it should be used with some reservations.

\subsection{Project II}

The interpretation of the geological maps indicated that the surrounding areas of the road section were comprised of ortho-gneisses of granitoid composition (Ref 24). The sediment-gneisses, mica-schists and phyllites are subordinate

Table 2 Results of the calculations of content of free mica particles in fine fraction $(0.125-0.25 \mathrm{~mm})$, Project I, phase 1

\begin{tabular}{lc}
\hline Sample ID & Mica content, vol.\% \\
\hline P1-1-01 & 49.5 \\
P1-1-02 & 36.0 \\
P1-1-03 & 27.5 \\
P1-1-04 & 36.0 \\
P1-1-05 & 29.9 \\
P1-1-06 & 23.5 \\
P1-1-07 & 24.6 \\
\hline
\end{tabular}

to the ortho-gneisses. The petrographic analyses of the drill cuttings estimated the rock materials to be composed of grey to light grey to pink, foliated, coarse-grained, irregulargrained ortho-gneiss with feldspar, quartz, and mica (biotite) as the main mineral constituents (Table 6). Some samples showed a finer grained ortho-gneiss. The content of free mica particles in the fine fractions was determined as $19-41 \%$ (Table 7).

The rock types investigated were estimated to meet the technical demands (Ref 15) for both base course and sub-base course in unbounded road pavements. The finer grained orthogneisses were considered to display better mechanical properties than the coarse-grained ones. The phase 2 of this project has been delayed. Final analysis of the mineral will occur at after the conclusion of the current project.

\subsection{Project III}

The geological maps of the area describe a metamorphic, heterogeneous bedrock mainly composed of granofels, including metamorphic rocks of both sedimentary and igneous origin. The results of the field investigations and the petrographic analyses (Table 8) of the coarse fraction of the drill cuttings showed several rock types:

(i) foliated, medium-grained, mica-rich, biotite-plagioclaseschist,

(ii) dark grey, medium-grained, irregular-grained amphiboliteschist,

(iii) biotite-rich, medium- to coarse-grained ortho-gneiss.

The two first rock types are weakly to medium migmatised and partly mylonitised; altered into chlorite-schist. The orthogneiss is strongly tectonised, exhibiting a high frequency of micro-cracks. The analysis of free mica particle content in the

Table 4 Results of the calculations of content of free mica particles in fine fraction $(0.125-0.25 \mathrm{~mm})$, Project I, phase 2

\begin{tabular}{lc}
\hline Sample ID & Mica content, vol.\% \\
\hline P1-2-01 & 45.0 \\
P1-2-02 & 32.6 \\
\hline
\end{tabular}

Table 5 Results of the mechanical analyses, Project I, phase 2

\begin{tabular}{lccccc}
\hline $\begin{array}{l}\text { Sample } \\
\text { ID }\end{array}$ & $\begin{array}{c}\text { Density, } \\
\mathbf{M g} / \mathbf{m}^{\mathbf{3}}\end{array}$ & $\begin{array}{c}\text { micro-Deval, } \\
\text { \% }\end{array}$ & $\begin{array}{c}\text { Los } \\
\text { Angeles, \% }\end{array}$ & $\begin{array}{c}\text { Nordic } \\
\text { test, \% }\end{array}$ & $\begin{array}{c}\text { Flakiness } \\
\text { index, \% }\end{array}$ \\
\hline P1-2-01 & 2.74 & 19 & 32 & 26.2 & 12 \\
P1-2-02 & 2.71 & 20 & 34 & 30.3 & 19 \\
\hline
\end{tabular}

Table 3 Results of the petrographic analyses, Project I, phase 2; rock type and mineralogical composition

\begin{tabular}{|c|c|c|c|c|c|c|}
\hline Sample ID & Rock type & Grain size, mm & Feldspar, vol. $\%$ & Quartz, vol.\% & Mica, vol. $\%$ & Others, vol. $\%$ \\
\hline P1-2-01 & Ortho-gneiss & $2-3$ & 35.2 & 28.9 & 35.9 & $\ldots$ \\
\hline P1-2-02 & Migmatite (mica-schist/ortho-gneiss) & 0.2 to $>2$ & 51.6 & 31.0 & 17.4 & $\cdots$ \\
\hline
\end{tabular}


Table 6 Results of the petrographic analyses, Project II, phase 1; rock type and mineralogical composition

\begin{tabular}{|c|c|c|c|c|c|c|c|}
\hline Sample ID & Rock type & Grain size, mm & Feldspar, vol. $\%$ & Quartz, vol.\% & Mica, vol. $\%$ & Amphibol, vol. $\%$ & Others, vol. $\%$ \\
\hline P2-1-01 & Ortho-gneiss & $0.5-4$ & 70.7 & 17.7 & 10.5 & $\ldots$ & 1.1 \\
\hline P2-1-02 & Ortho-gneiss & $0.5-4$ & 65.4 & 19.1 & 10.9 & 3.5 & 1.1 \\
\hline P2-1-03 & Ortho-gneiss & $0.2-4$ & 68.3 & 26.5 & 3.7 & $\ldots$ & 1.5 \\
\hline P2-1-04 & Ortho-gneiss & $0.5-5$ & 67.6 & 14.5 & 17.9 & $\ldots$ & $\ldots$ \\
\hline P2-1-05 & Ortho-gneiss & $1-4$ & 52.0 & 35.1 & 11.9 & $\ldots$ & 1.0 \\
\hline P2-1-06 & Ortho-gneiss & $1-5$ & 51.0 & 33.3 & 11.4 & $\ldots$ & 4.3 \\
\hline P2-1-07 & Ortho-gneiss & $1-4$ & 68.9 & 16.8 & 12.7 & $\ldots$ & 1.6 \\
\hline P2-1-08 & Ortho-gneiss & $0.5-5$ & 68.9 & 20.2 & 10.3 & $\ldots$ & 0.5 \\
\hline P2-1-09 & Ortho-gneiss & $1-2$ & 60.8 & 27.6 & 11.6 & $\ldots$ & $\ldots$ \\
\hline
\end{tabular}

Table 7 Results of the calculations of content of free mica particles in fine fraction $(0.125-0.25 \mathrm{~mm})$, Project II, phase 1

\begin{tabular}{lc}
\hline Sample ID & Mica content, vol.\% \\
\hline P2-1-01 & 27.1 \\
P2-1-02 & 36.2 \\
P2-1-03 & 28.6 \\
P2-1-04 & 40.7 \\
P2-1-05 & 19.4 \\
P2-1-06 & 30.9 \\
P2-1-07 & 34.7 \\
P2-1-08 & 37.0 \\
\hline
\end{tabular}

Table 9 Results of the calculations of content of free mica particles in fine fraction $(0.125-0.25 \mathrm{~mm})$, Project III, phase 1

\begin{tabular}{lc}
\hline Sample ID & Mica content, vol.\% \\
\hline P3-1-01 & 45.3 \\
P3-1-02 & 46.6 \\
P3-1-03 & 46.3 \\
P3-1-04 & 23.7 \\
P3-1-05 & 50.5 \\
P3-1-06 & 0 \\
P3-1-07 & 0 \\
P3-1-08 & 1.0 \\
P3-1-09 & 44.6 \\
P3-1-10 & 45.4 \\
P3-1-11 & 46.3 \\
\hline
\end{tabular}

Table 8 Results of the petrographic analyses, Project III, phase 1; rock type and mineralogical composition

\begin{tabular}{|c|c|c|c|c|c|c|c|}
\hline Sample ID & Rock type & Grain size, mm & Feldspar, vol.\% & Quartz, vol.\% & Mica, vol.\% & Amphibol, vol.\% & Others, vol.\% \\
\hline P3-1-01 & Mica-schist & $0.1-0.7$ & 44.7 & 21.4 & 33.8 & $\ldots$ & $\ldots$ \\
\hline P3-1-02 & Mica-schist & $0.1-0.7$ & 37.8 & 6.7 & 55.4 & $\ldots$ & $\ldots$ \\
\hline P3-1-03 & Mica-schist & $0.1-0.7$ & 49.1 & 20.6 & 30.3 & $\ldots$ & $\ldots$ \\
\hline P3-1-04 & Mica-schist & $0.1-0.7$ & 47.8 & 17.3 & 34.9 & $\ldots$ & $\ldots$ \\
\hline P3-1-05 & Mica-schist & $0.1-0.4$ & 36.0 & 9.7 & 53.8 & $\ldots$ & 0.4 \\
\hline P3-1-06 & Amphibolite-schist & $0.5-1$ & 39.6 & $\ldots$ & $\ldots$ & 59.6 & 0.8 \\
\hline P3-1-07 & Amphibolite-schist & $0.4-1$ & 39.9 & $\ldots$ & $\ldots$ & 57.1 & 3.0 \\
\hline P3-1-08 & Amphibolite-schist & $0.1-0.2$ & 32.7 & $\ldots$ & $\ldots$ & 67.3 & $\ldots$ \\
\hline P3-1-09 & Ortho-gneiss & $0.1-7$ & 43.7 & 30.3 & 26.0 & $\ldots$ & $\ldots$ \\
\hline P3-1-10 & Ortho-gneiss & $0.1-7$ & 70.8 & 13.5 & 15.7 & $\ldots$ & $\ldots$ \\
\hline P3-1-11 & Ortho-gneiss & $0.1-5$ & 34.6 & 20.4 & 45.0 & $\ldots$ & $\ldots$ \\
\hline
\end{tabular}

fine fractions revealed values from 0 to over $50 \%$ (Table 9). The amphibolite-schist is lacking mica; all other rocks are mica-rich.

Despite the negative petrographic indications, the mechanical tests of the rock samples (Table 10) resulted in values approved for use in base course (Ref 15). The evaluation of the investigation presented a general recommendation to limit the construction traffic on unbound layers in order to avoid fragmentation.

\section{Discussion and Evaluation}

The samples of drill cuttings selected in Projects I and II originated from soil/rock probing performed during the planning stage of the road construction project. The analyses of the
Table 10 Results of the mechanical analyses, Project III, phase 2

\begin{tabular}{lccccc}
\hline $\begin{array}{l}\text { Sample } \\
\text { ID }\end{array}$ & $\begin{array}{c}\text { Density, } \\
\mathbf{M g} / \mathbf{m}^{3}\end{array}$ & $\begin{array}{c}\text { micro-Deval, } \\
\text { \% }\end{array}$ & $\begin{array}{c}\text { Los } \\
\text { Angeles, \% }\end{array}$ & $\begin{array}{c}\text { Nordic } \\
\text { test, \% }\end{array}$ & $\begin{array}{c}\text { Flakiness } \\
\text { index, \% }\end{array}$ \\
\hline P3-2-01 & 2.71 & 10 & 21 & 15.4 & 14.4 \\
P3-2-02 & 2.97 & 17 & 18 & 20.1 & 12.9 \\
P3-2-03 & 2.70 & 20 & 22 & 22.6 & 9.3 \\
\hline
\end{tabular}

drill cutting samples resulted in a prognosis concerning the use of the aggregate for the particular road construction. The latter petrographic and mechanical analyses of the samples collected from the exposed bedrock and from the crushed aggregate products confirmed the primary prognoses based on the 
analyses of drill cuttings. The sampling of drill cuttings in Project III was done during production drilling, since phases 1 and 2 were carried out simultaneously. However, the results of the analyses of drill cuttings and the results of the geological and the mechanical analyses of the rock samples and the aggregates produced were well correlated. The different approaches of sampling indicate the independence of the field sampling technique and stress the flexibility of the drill cutting method and its application as a field method. The utilization of the soil/rock probing method provides an opportunity to collect bedrock data during the planning stage of the project with the possibility of performing a volumetric and quality estimation of the rock mass available.

Mechanical properties of rocks are closely connected to their geological properties (e.g., Ref 25-30). Thus, mechanical analyses used for estimation of the quality of aggregates are not sufficient to evaluate the usability of crushed rock. On the contrary, advanced geological analyses do not give information on the quality or the usability of the rock aggregate, if the geological parameters are not interpreted into functional characteristics. The interpretation in turn depends on the experience and the ability of the interpreter to interconnect the geological and the mechanical properties and to understand the processing of different rock materials.

The results of this study point out the potential use of the drill cutting method as a surveying tool for road and railway constructions and for quarry establishment. This method is easily applied even when the bedrock is covered by drift materials (i.e., by soil/rock probing). The most desirable advantage of the method is its timings and cost efficiency. However, the method is also highly flexible and can be used to support quality estimation of rock materials. The predictions of the quality and the usability of rock materials in the current investigation have been satisfactorily confirmed.

In an effort to further develop and calibrate the method of drill cuttings, evaluation of rock aggregate including the phase 3 process will be continued. Furthermore, because the investigation deals with metamorphic rocks, further research within different geological environments (i.e., igneous and sedimentary rocks) is required.

\section{Conclusion}

The results from this work confirm the necessity of a quick and reliable method for quality estimation of the rock materials during the planning stage of road constructions, quarry prospecting, etc. Using drill cuttings from introductory geotechnical investigations for estimation of the rock materials' mechanical properties is the most efficient method for achieving this purpose. To turn the petrographic properties of the rocks into an estimate of their mechanical properties, and to evaluate their suitability as aggregates in the different parts of road construction, demands experience of the interpreters.

\section{Acknowledgment}

This study was funded by the Swedish Road Administration (SRA) and the Swedish National Road and Transport Research Institute (VTI).

\section{References}

1. The Swedish Road Administration, Miljökonsekvensbeskrivning inom vägsektorn, Del 3 Analys och bedömning, Publikation 2002:43, Vägverket (the Swedish Road Administration), Borlänge, 2002, p 171 (in Swedish), http://publikationswebbutik.vv.se/upload/1896/ 2002_43_handbok_miljokonsekvensbeskrivning_inom_vagsektorn_del_ 3_analys_och_bedomning.pdf (2008-05-14)

2. M.R. Smith and L. Collis, Eds., Aggregates: Sand, Gravel and Crushed Rock Aggregates for Construction Purposes, 3rd edn., vol. 17. Geological Society, London, Engineering Geology Special Publications, 2001, p 339

3. M. Heiniö, Ed., Rock Excavation Handbook, Sandvik Tamrock Corp., 1999, p 363

4. H. Hakim and S. Said, Glimmer $i$ bitumenbundna beläggningar Inverkan av fina, fria glimmerkorn, VTI notat 8-2003, Statens väg- och transportforskningsinstitut (the Swedish National Road and Transport Research Institute), Linköping, 2003, p 36 (in Swedish), http://www. vti.se/EPiBrowser/Publikationer/N8-2003.pdf (2008-04-03)

5. K. Miskovsky, Enrichment of Fine Mica Originating from Rock Aggregate Production and its Influence on the Mechanical Properties of Bituminous Mixtures, J. Mater. Eng. Perform., 2004, 13(5), p 607-611

6. P. Nieminen and R. Uusinoka, Influence of Quality of Fine Fractions on Engineering Geological Properties of Crushed Aggregates, Bull. Int. Assoc. Eng. Geol., 1986, 33(1), p 97-101

7. S.L. Brantley and N.P. Mellott, Surface Area and Porosity of Primary Silicate Minerals, Am. Mineral., 2000, 85(11-12), p 1767-1783

8. B. Lagerblad, Krossat berg som ballast $i$ betong, Område 2, Projekt nr 2,2 Framtida betong, Delprojekt 2,23 Utnyttjande av alternativa typer av ballast i betong, Rapport nr 2:19, MinBaS, Stockholm, 2005, p 68 (in Swedish)

9. K.-J. Loorents, E. Johansson, and H. Arvidsson, Free Mica Grains in Crushed Rock Aggregates, Bull. Eng. Geol. Environ., 2007, 66(4), p 441-447

10. The Swedish Geotechnical Society, Geoteknisk fälthandbok Allmänna råd och metodbeskrivningar, SFG Rapport 1:96, Svenska Geotekniska Föreningen (the Swedish Geotechnical Society), Linköping, March, 1996, p 172 (in Swedish), http://www.sgf.net/home/ page.asp? sid=862\&mid=2\&PageId=11564 (2008-05-14)

11. Tests for General Properties of Aggregates - Part 2: Methods for Reducing Laboratory Samples, EN 932-2:1999, European Committee for Standardization, 1999

12. Tests for Geometrical Properties of Aggregates - Part 1: Determination of Particle Size Distribution - Sieving Method, EN 933-1:1997, European Committee for Standardization, 1997

13. I. Sims and P. Nixon, RILEM Recommended Test Method AAR-1: Detection of Potential Alkali-Reactivity of Aggregates - Petrographic Method, Mater. Struct./Matér. Construct., 2003, 36(7), p 480-496

14. W.D. Nesse, Introduction to Optical Mineralogy, Oxford University Press, 2004, p 348

15. Allmän teknisk beskrivning för vägkonstruktion ATB Väg 2005, Publikation 2005:112, Vägverket (the Swedish Road Administration), Borlänge, 2005 (in Swedish), http://www.vv.se/templates/page3 14328.aspx (2008-05-14)

16. F. Chayes, Petrographic Modal Analysis, Wiley, New York, 1956

17. A.A. Glagolev, Mineralogical Materials, 1931, p 10

18. E. Johansson, K. Miškovský, K.-J. Loorents, and O. Löfgren, A Method for Estimation of Free Mica Particles in Aggregate Fine Fraction by Image Analysis of Grain Mounts, J. Mater. Eng. Perform., 2008, 17(2), p 250-253

19. Tests for Mechanical and Physical Properties of Aggregates - Part 1: Determination of the Resistance to Wear (micro-Deval), EN 10971:1996, European Committee for Standardization, 1996

20. Test for Mechanical and Physical Properties of Aggregates - Part 2: Methods for the Determination of Resistance to Fragmentation, EN 1097-2:1998, European Committee for Standardization, 1998

21. Test for Mechanical and Physical Properties of Aggregates - Part 6: Determination of Particle Density and Water Absorption, EN 10976:2000, European Committee for Standardization, 2000

22. Test for Mechanical and Physical Properties of Aggregates - Part 9: Determination of the Resistance to Wear by Abrasion from Studded 
Tyres - Nordic Test, EN 1097-9:1998, European Committee for Standardization, 1998

23. Tests for Geometrical Properties of Aggregate - Part 3: Determination of Particle Shape - Flakiness Index, EN 933-3:1997, European Committee for Standardization, 1997

24. A. Streckeisen, To Each Plutonic Rock Its Proper Name, Earth Sci. Rev., 1976, 12(1), p 1-33

25. B. Brattli, The Influence of Geological Factors on the Mechanical Properties of Basic Igneous Rocks Used as Road Surface Aggregates, Eng. Geol., 1992, 33(1), p 31-44

26. A. Tuğrul and I.H. Zarif, Correlation of Mineralogical and Textural Characteristics with Engineering Properties of Selected Granitic Rocks from Turkey, Eng. Geol., 1999, 51(4), p 303-317
27. U. Åkesson, J.E. Lindqvist, M. Göransson, and J. Stigh, Relationship Between Texture and Mechanical Properties of Granites, Central Sweden, by Use of Image-Analysing Techniques, Bull. Eng. Geol. Environ., 2001, 60(4), p 277-284

28. U. Åkesson, J. Stigh, J.E. Lindqvist, and M. Göransson, The Influence of Foliation on the Fragility of Granitic Rocks, Image Analysis and Quantitative Microscopy, Eng. Geol., 2003, 68(3-4), p 275-288

29. M. Räisänen, Relationships Between Texture and Mechanical Properties of Hybrid Rocks from the Jaala-Iitti Complex, Southeastern Finland, Eng. Geol., 2004, 74(3-4), p 197-211

30. M. Räisänen and A. Torppa, Quality Assessment of a Geologically Heterogeneous Rock Quarry in Pirkanmaa County, Southern Finland, Bull. Eng. Geol. Environ., 2005, 64(4), p 409-418 